\title{
Debris flow susceptibility mapping using a qualitative heuristic method and Flow-R along the Yukon Alaska Highway Corridor, Canada
}

\author{
A. Blais-Stevens and P. Behnia \\ Geological Survey of Canada, 601 Booth Street, Ottawa, K1A0E8, Canada \\ Correspondence to: A. Blais-Stevens (andree.blais-stevens@ canada.ca) \\ Received: 24 April 2015 - Published in Nat. Hazards Earth Syst. Sci. Discuss.: 29 May 2015 \\ Revised: 2 December 2015 - Accepted: 18 January 2016 - Published: 11 February 2016
}

\begin{abstract}
This research activity aimed at reducing risk to infrastructure, such as a proposed pipeline route roughly parallel to the Yukon Alaska Highway Corridor (YAHC), by filling geoscience knowledge gaps in geohazards. Hence, the Geological Survey of Canada compiled an inventory of landslides including debris flow deposits, which were subsequently used to validate two different debris flow susceptibility models. A qualitative heuristic debris flow susceptibility model was produced for the northern region of the YAHC, from Kluane Lake to the Alaska border, by integrating data layers with assigned weights and class ratings. These were slope angle, slope aspect, surficial geology, plan curvature, and proximity to drainage system. Validation of the model was carried out by calculating a success rate curve which revealed a good correlation with the susceptibility model and the debris flow deposit inventory compiled from air photos, high-resolution satellite imagery, and field verification. In addition, the quantitative Flow-R method was tested in order to define the potential source and debris flow susceptibility for the southern region of Kluane Lake, an area where documented debris flow events have blocked the highway in the past (e.g. 1988). Trial and error calculations were required for this method because there was not detailed information on the debris flows for the YAHC to allow us to define threshold values for some parameters when calculating source areas, spreading, and runout distance. Nevertheless, correlation with known documented events helped define these parameters and produce a map that captures most of the known events and displays debris flow susceptibility in other, usually smaller, steep channels that had not been previously documented.
\end{abstract}

\section{Introduction}

Debris flow modelling has been carried out by several researchers - e.g. Costa (1984), Hungr et al. (1984), Berti and Simoni (2007), Beguería et al. (2009), Hussin et al. (2012), and Fischer et al. (2012), among many others. Over the past decades, there have been ongoing discussions about building a pipeline roughly parallel to the Yukon Alaska Highway Corridor, in northern Canada (YAHC; Fig. 1a). Portions of the proposed pipeline route intersect critical geological regions and areas prone to geological hazards, such as landslides including debris flows, earthquakes due to active faults, subsidence from thermo-karstic erosion, and permafrost degradation. One of the roles of the Geological Survey of Canada (GSC), as part of Natural Resources Canada, is to reduce risk of geohazards to critical linear infrastructure, such as a proposed pipeline project by providing baseline geoscience information to decision makers.

The YAHC is roughly $875 \mathrm{~km}$ long and about $40 \mathrm{~km}$ wide and covers roughly $22000 \mathrm{~km}^{2}$ as it does not include the portions that extend into British Columbia (Fig. 1a). As a first step in assessing the types of geohazards, the GSC in collaboration with the Yukon Geological Survey (Huscroft et al., 2004), compiled an inventory of geological hazards, particularly landslides (Blais-Stevens et al., 2010a). Several landslide types were observed including debris flows, debris slides, rockfalls, rock slides, active layer detachment slides, retrogressive thaw slumps, among others (Blais-Stevens et al., 2011). Once the baseline landslide information was compiled, the next step was to provide an overview of the landslide distribution and landslide "hot spots" by plotting distribution maps and producing regional qualitative landslide 


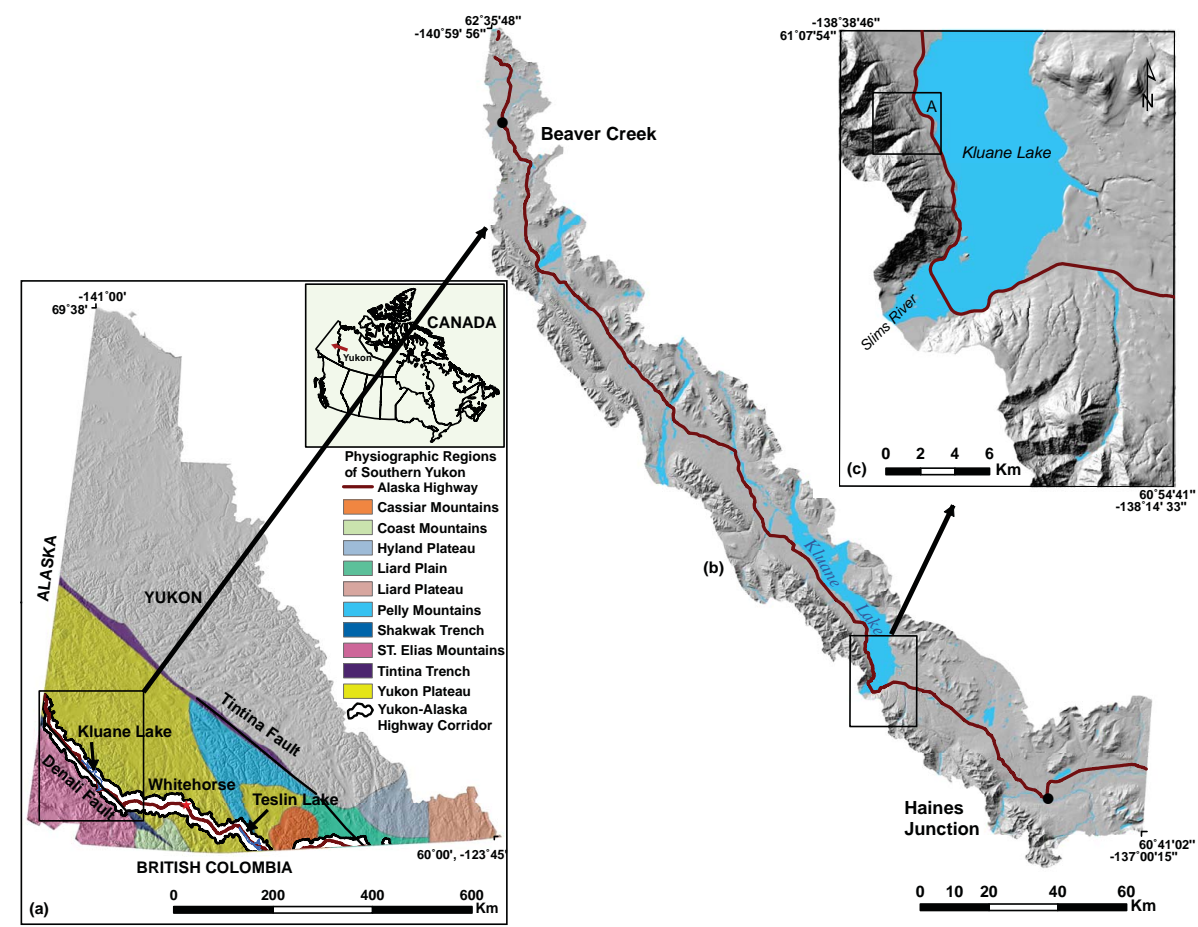

Figure 1. (a) Physiographic setting of southern Yukon (modified from Mathews, 1986 and Huscroft et al., 2004) and (b) northern portion of YAHC where regional debris flow susceptibility mapping was carried out. (c) South end of Kluane Lake area where the quantitative susceptibility assessment was performed. Box A shows the location of Fig. 4.

susceptibility maps (Blais-Stevens et al., 2010b, 2011, 2012, 2014; Couture et al., 2010). Different susceptibility models were created for different types of landslides, namely rockfall/rock slides, active layer detachment slides, retrogressive thaw slumps, and debris flows.

Choosing which landslide susceptibility method to apply in our study area depended on several factors. Some of the factors were scale, availability of geological and geomorphological data in digital format, software and hardware capabilities, and technical experience with GIS platform (Soeters and van Westen, 1996; van Westen et al., 2008). For the entire YAHC, we chose the simplest approach - a qualitative heuristic method - as the study area was vast and uniform geological information was available at a broad scale. We modified and adapted the models first used for landslides triggered in permafrost along the Mackenzie Valley (Riopel et al., 2006) and other types of landslides (including debris flows) for the Sea to Sky Highway in southern British Columbia (Blais-Stevens et al., 2012). Furthermore, previous studies revealed that debris flows along the Alaska Highway had occurred previously and blocked the highway, particularly in the south end of Kluane Lake where the highway was built close to steep slopes (Evans and Clague, 1989; Lipovsky, 2005; Koch et al., 2014; Fig. 1c). Such an event occurred in 1988 following a torrential downpour; the highway was blocked by debris for 7 days (Evans and Clague, 1989; Lipovsky, 2005). Therefore, with a higher resolution Digital
Elevation Model (DEM; $10 \times 10 \mathrm{~m}$ ), we used a quantitative method using Flow-R to assess the potential source areas in steep channels and corresponding debris flow susceptibility (Horton et al., 2013) in the area where documented debris flows had occurred. Hence, the objectives of the paper are to (1) assess the regional debris flow susceptibility using a qualitative heuristic method for the northern portion of the corridor (Fig. 1b), a method used to highlight the potential zones of initiation; (2) for the south end of Kluane Lake (Fig. 1c), define the local potential source areas for debris flows; and (3) model the debris flow susceptibility by calculating propagation and spreading, using the quantitative Flow-R method.

\section{Physiographic setting and geology}

The Yukon Alaska Highway Corridor traverses 10 physiographic regions. From northwest to east in a broad sense, the relief varies from mountainous to rounded hills, to lowlands. The maximum elevation within the study area is $2799 \mathrm{~m}$, located roughly southeast of the southernmost point of Kluane Lake and the minimum elevation, and occurs about $15 \mathrm{~km}$ west of Haines Junction (Fig. 1b). Two major faults cut across the YAHC, namely the Denali and Tintina faults (Fig. 1a). For a detailed description of the physiographic regions, the reader is referred to Mathews (1986) and Huscroft et al. (2004). 
The YAHC tectonic setting is largely the result of 190 million years of accretion of exotic terranes and intervening sediments onto the ancient North American continental plate (Gordey and Makepeace, 2003; Huscroft et al., 2004). Along the YAHC, from west to east, the Kluane ranges are composed of young sedimentary rocks $(<150$ Ma old). Further east, felsic intrusions dominate within the Yukon Plateaus. Towards Whitehorse, Upper Cretaceous volcanic rocks and valley-filling Quaternary basalts are exposed. Within the Liard Lowland eastward, there are outcrops of Paleozoic sedimentary rocks (Gordey and Makepeace, 2003; Huscroft et al., 2004).

The abundance of surficial sediments along the YAHC is the result of several Quaternary glaciations. Hillslopes are covered by till blankets and veneer. Coarser ice-marginal meltwater deposits are commonly flanked along these hillslopes. In the steep mountainous terrain, weathered bedrock and reworked till form colluvium along valley sides. These are a major source for mass movement within the YAHC (Huscroft et al., 2004).

\subsection{Climate and vegetation}

The study area is characterized by a sub-arctic continental climate with long, cold winters, and short mild summers with low relative humidity and low to moderate precipitation averaging $340 \mathrm{~mm}$ per year. The mean daily temperatures vary from $-27{ }^{\circ} \mathrm{C}$ in January to $27^{\circ} \mathrm{C}$ in July (Huscroft et al., 2004). The YAHC lies within the Boreal Forest Ecozone, which is dominated by white and black spruce. Trembling aspen grows in meadows and open forests. The treeline varies between $1400 \mathrm{~m}$ in the east and $1200 \mathrm{~m}$ in the northwest corridor (Huscroft et al., 2004).

\section{Previous work}

Landslide characterization and inventory compilation in the Yukon was carried out by Huscroft et al. (2004). BlaisStevens et al. (2010a) published a regional landslide inventory based solely on aerial photo interpretation (1960-1990 aerial photos from National Air-Photo Library) that also included the contribution by Huscroft et al. (2004). Interpretation of high-resolution satellite imagery (WorldView-2) collected in 2010 helped fine tune and update the inventory that was used to validate regional landslide susceptibility models as well as field verification (Blais-Stevens et al., 2010b, 2011, 2012).

Horton et al. $(2008,2013)$ used a distributed empirical model that can be transposed to a small area within YAHC where an inventory of past events exist. In addition to the qualitative heuristic method, the south portion of the Kluane Lake, an area adjacent to the Kluane Ranges (Fig. 1a, b, and c) was a suitable area to test this method because (1) a highresolution DEM was available for this area, (2) the area has witnessed extreme debris flow events (July 1988), and (3) it contained several mapped debris flow deposits to validate the model.

\section{Regional qualitative heuristic susceptibility mapping}

The qualitative approach used for landslide susceptibility mapping is a simple heuristic approach modified from Soeters and van Westen (1996), Riopel et al. (2006), and Blais-Stevens et al. (2012). Previous publications by BlaisStevens et al. (2010b, 2011, 2012) demonstrated landslide susceptibility mapping for the entire corridor using a $30 \times 30 \mathrm{~m} \mathrm{DEM}\left(22000 \mathrm{~km}^{2}\right.$; Fig. 1a). In this study, we focused on the northern portion, the more mountainous region of the corridor $\left(7600 \mathrm{~km}^{2}\right.$ Fig. 1b) and used a similar approach, but with a higher-resolution DEM $(5 \times 5 \mathrm{~m}$ generated by Natural Resources Canada's Canadian Centre for Geospatial Information, 2014, using Canvec products and Topo to Raster tool in ArcGIS). The simple equation is defined by a susceptibility index for debris flows in which the instability factors served as the variables. Each variable was assigned a percent weight relative to each other based on expert knowledge according to its importance in slope instability. The factors of instability were derived from the surficial geology map or generated from DEM as data layers and consequently reclassified. Classes within each parameter were also rated based on their potential contribution to slope failure. The resulting parametric equation is the sum of all variables and represents a susceptibility index (SI) ranging between 0 and 1 for each pixel $(5 \times 5 \mathrm{~m})$. The heuristic modelling was carried out independently of the debris flow deposit inventory where it was later used to validate the susceptibility map. The criteria considered relevant to initiation of debris flows in the study area include proximity to drainage system, slope angle, sediment type, plan curvature, and slope aspect. The drainage was considered important as debris flows usually are triggered in steep streams. This data layer was generated by creating five buffer zones around the drainage system. Each zone was rated based on its proximity to the drainage system (Table 1). Slope angle was considered an equally important factor in initiation of a debris flow based on expert knowledge and the literature. According to Ortigao and Kanji (2004), the minimum slope angles reported in the literature are above 20 to $25^{\circ}$. There is an increase in the number of debris flows as the slope angle increases. At slope angles higher than 34 to $37^{\circ}$, there is a decrease because of the existence of rock scarps (Ortigao and Kanji, 2004). Similarly, Dai and Lee (2001) noted that at slope gradients $\geq 40^{\circ}$, the slope forming material of the terrain is composed of weathered rock which is stronger and less prone to failure than colluvium. Thus, the slope map was generated from a $5 \times 5 \mathrm{~m}$ DEM and was reclassified into five classes and assigned the highest rating to slope angles ranging from $25-45^{\circ}$ (Table 1). Sediment availability is another 
Table 1. Debris flow parameters and class ratings.

\begin{tabular}{|c|c|c|c|c|c|}
\hline Surficial geology $(\mathrm{G})$ unit & Rating & Slope angle $\left({ }^{\circ}\right)(\mathrm{S} 1)$ & Rating & Slope aspect $\left(^{\circ}\right)(\mathrm{S} 2)$ & Rating \\
\hline Colluvium, tuff & 1.0 & $0-15$ & 0.1 & $0-45$ & 0.1 \\
\hline Eolian, lacustrine (vC, C), glacio-lacustrine (vC, C) & 0.7 & $15-25$ & 0.5 & $45-135$ & 0.5 \\
\hline Till, drift, glacio-lacustrine (M) & 0.5 & $25-45$ & 1.0 & $135-225$ & 1.0 \\
\hline Glacio-lacustrine $(\mathrm{F})$ & 0.4 & $45-55$ & 0.5 & $225-315$ & 0.5 \\
\hline Glaciofluvial & 0.3 & $56-90$ & 0.1 & $315-360$ & 0.1 \\
\hline Organics, alluvium, rock, anthropogenic & 0.1 & & & & \\
\hline Proximity to drainage (m) (D) & Rating & $\begin{array}{l}\text { Plan curvature } \\
\left(-1 / 100 \mathrm{~m}^{-1}\right)(\mathrm{C})\end{array}$ & Rating & & \\
\hline $0-50$ & 1.0 & $\leq-2$ & 1.0 & & \\
\hline $50-100$ & 0.75 & -2 to -0.5 & 0.8 & & \\
\hline $100-150$ & 0.5 & -0.5 to -0.1 & 0.5 & & \\
\hline $150-200$ & 0.25 & $>-0.1$ & 0.1 & & \\
\hline$>200$ & 0.1 & & & & \\
\hline
\end{tabular}

$\mathrm{vC}=$ very coarse, $\mathrm{C}=$ coarse, $\mathrm{M}=$ medium, $\mathrm{F}=$ fine.

important factor in initiation of debris flows, but to a slightly lesser extent relative to drainage and slope angle due to the broad scale of the surficial geology map relative to the DEM. The surficial geology map (Yukon Geological Survey, 2015) was thus reclassified into six classes based on the favourability of the sediments in developing debris and were rated accordingly (Table 1). Plan curvature was also a factor included in the equation as it reflects areas where debris can accumulate. The more concave the slope curvature, the higher the rating (Table 1). We also considered the direction of slope (i.e. the slope aspect) as a potential contributing factor, but to a lesser degree than the other data layers. The south-facing slope is more exposed to solar radiation. This, in turn, could contribute to either increased snow melt or permafrost thaw and subsequently to the drainage system. The slope aspect map, also generated from the $5 \times 5 \mathrm{~m}$ DEM, was reclassified into five classes, with the highest ratings assigned to slopes facing SE to SW (Table 1). All geological information was compiled and processed on an ArcGIS platform (v. 10.2.2). Once the parameter maps were reclassified and rated, they were integrated using

$\mathrm{SI}=0.3 D+0.3 S 1+0.2 G+0.15 C+0.05 S 2$,

where $D$ is proximity to drainage system, $S 1$ is the slope angle, $G$ is the type of surficial geology deposit, $C$ is the plan curvature, and $S 2$ is the slope aspect. The resulting debris flow susceptibility map (Fig. 2) shows a susceptibility index (SI) ranging from 0 to 1 in which the high values are the areas of high susceptibility (shown in red). Although the highly susceptible areas are dominant in the most western region of the corridor, there are areas of high susceptibility found close to the highway, near Kluane Lake.

We used the mapped debris flow inventory consisting of 306 deposits to evaluate the debris flow susceptibility map. Given that the inventory only includes the deposits and not the initiation zones, we made the assumption that the source area likely occurs within at least $500 \mathrm{~m}$ distance uphill from the apex of the deposit. There are potentially other source areas uphill from these minimum distances (as shown in the Flow-R method below), but our assumption is based on what we consider a realistic minimum limit for most of the steep streams. To delineate the potential source area (initiation zone), the stream network was extracted from the flow accumulation map and catchment basins were created from the apex of each debris flow deposit. Areas $100 \mathrm{~m}$ around the streams were selected and were intersected with the catchment basins. The areas covered by both catchment basins and streams within $500 \mathrm{~m}$ upstream from the debris flow deposits were selected as potential source areas (Fig. 5) where the maximum susceptibility value occurring within each polygon was extracted. A success rate of prediction curve was generated by plotting the cumulative percentage area from high to low susceptibility against the cumulative percentage of debris flow sources predicted (Chung and Fabbri, 2003). The qualitative heuristic susceptibility map shows a high prediction rate with respect to debris flow source areas (Fig. 3). About 80 and $90 \%$ of the debris flow sources are predicted within the top $5.5 \%$ and $10.5 \%$ of high susceptibility areas, respectively.

\section{Quantitative susceptibility mapping - Flow-R application to the southern end of Kluane Lake, YAHC}

We used the Flow-R model developed by Horton et al. (2008, 2013) to assess debris flow susceptibility and focus on a smaller area of the YAHC at the south end of Kluane Lake. Flow-R, developed under Matlab ${ }^{\circledR}$ by Horton et al. (2013) stands for Flow path assessment of gravitational hazards at 


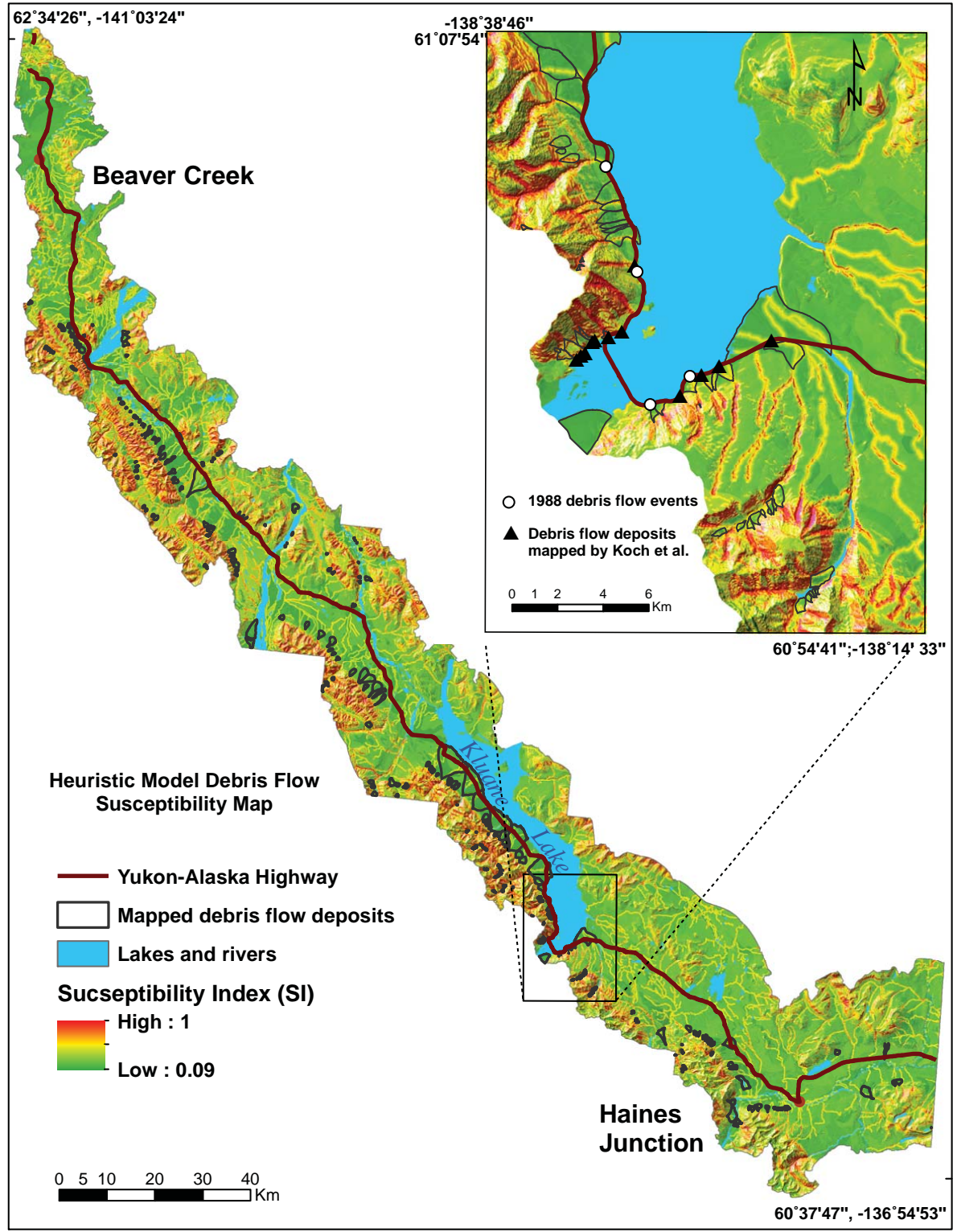

Figure 2. Debris flow susceptibility map created using the qualitative heuristic method for the northern part of YAHC (Fig. 1b). Inset map shows the southern end of the Kluane Lake area (Fig. 1c).

a Regional scale and was downloaded from www.flow-r.org. The main data set required for susceptibility assessment in Flow-R is a grid-based DEM. The quality of DEM is of great importance for the accuracy of the results. We used a $5 \times 5 \mathrm{~m}$ DEM and resampled it to $10 \mathrm{~m}$ in order to reduce the roughness and avoid the effect of channelization that can occur with very high resolution data so that a wider propagation could be captured within the fans. The following concepts of Flow-R and the implemented models are summarized from Horton et al. (2013). Susceptibility assessment using Flow-R involves two stages:

Step 1 - Delineation of debris flow source areas based on the geological, morphological, and hydrological criteria crit- ical in debris flow occurrence. These controlling parameters are used in grid format and are classified according to their favourability in debris flow initiation. The data are classified as favourable if initiation is possible, excluded if the initiation is unlikely, and ignored if there is not enough evidence in favourability of the class. The classified input parameters are integrated based on the following rule: a grid cell is considered a source area if it was classified as favourable in at least one of the parameter maps, but was never classified as excluded (Horton et al., 2013).

Step 2 - Propagation of the source areas. The potential source areas are propagated using two types of algorithms: (1) spreading algorithms which determine the path and the 


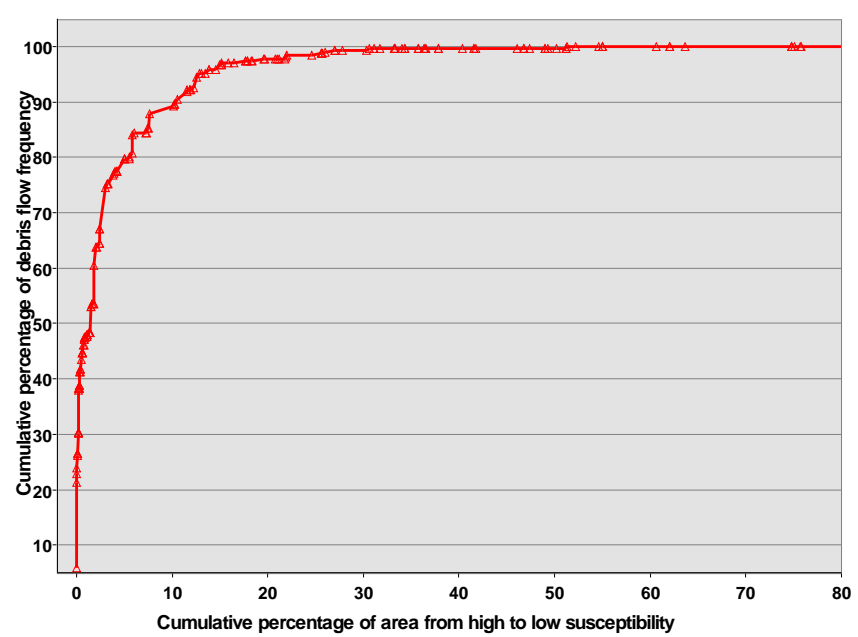

Figure 3. Prediction rate of qualitative heuristic debris flow susceptibility map represents a good correlation between debris flow susceptibility and inventory.

way debris flows spread and (2) algorithms which are based on the friction laws and control the runout distance of debris (Horton et al., 2013).

The spreading algorithms address flow direction algorithms and persistence functions and describe downslope movement of material. We used the flow direction algorithm of Holmgren (1994) and applied the height factor added by Horton et al. (2013) in order to smooth the roughness of the DEM and obtain a more consistent spreading. Another influencing factor which is implemented in Flow- $\mathrm{R}$ is inertial parameter. The flow direction is weighted based on the change in direction according to the persistence function. The weights resulted from the persistence function and those from flow direction are combined to provide the overall susceptibility (see Gamma, 2000 and Horton et al., 2013 for equations).

The runout distance algorithms control the distance which can be reached by debris flows. Two types of algorithms are available in Flow-R to assess the friction loss: a twoparameter friction model based on Perla et al. (1980) and a simplified friction model based on maximum possible runout distance. The Perla model, used in this study, is based on a non-linear friction law and calculates the velocity of the flow at the end of segment $i$. The model requires the value of friction coefficient $\mu$ and mass-to-drag ratio $\omega$ to be provided. In order to keep the energy within reasonable values, a maximum threshold is introduced to avoid achieving unrealistic velocities.

\subsection{Source area delineation}

In order to delineate the source areas in the study area, we considered slope angle and curvature as the morphological factors, upslope contributing area as the hydrological factor, and surficial geology as the lithological factor.

Slope angles above 20 to $25^{\circ}$ are reported by Ortigao and Kanji (2004) for initiation of most debris flows in the literature. According to Takahashi (1981) and Rickenmann and Zimmermann (1993), most debris flows occur at slope angles higher than $15^{\circ}$ (Horton et al., 2013). We considered this value as the lower initiation slope angle in this study area for this method.

The plan curvature was used to identify the concave curvatures as possible source areas based on the assumption that debris flows tend to occur in gullies where the curvature is concave. There is no established threshold value for curvature in the literature. Horton et al. (2013) used a curvature of $-2 / 100 \mathrm{~m}^{-1}$ based on a $10 \mathrm{~m}$ DEM, and analysis of orthophotographs in Switzerland. Fischer et al. (2012) used values from $-1.5 / 100 \mathrm{~m}^{-1}$ to $-0.5 / 100 \mathrm{~m}^{-1}$ for debris flow susceptibility mapping in Norway and Park et al. (2013) used curvature values from $-2 / 100 \mathrm{~m}^{-1}$ to $-1 / 100 \mathrm{~m}^{-1}$ for debris flow hazard zonation analysis in Korea. In order to establish a proper curvature threshold for the study area, we tested two threshold values of $-1.5 / 100 \mathrm{~m}^{-1}$ and $-1.0 / 100 \mathrm{~m}^{-1}$ to select the favourable source areas. The selected source areas and their resulting propagation areas were examined using the mapped debris flow deposits of the study area. Most of the mapped debris flow deposits were captured by the propagation area in both cases, but the threshold value of $-1.0 / 100 \mathrm{~m}^{-1}$ provided a better agreement and could capture more debris flow deposits (Fig. 4).

Water, commonly as infiltration of rainfall or convergence of ground water into the soil, contributes to instability of steep slopes by increasing the soil weight and decreasing the soil strength (Savage and Baun, 2005). To estimate the water input, the flow accumulation which represents the upslope contributing area was used. Based on the analysis of past debris flow events, a relationship could be established between the upslope contributing area and slope. Horton et al. (2008, 2013) defined two curves for identifying the lower limit of debris flow initiation in the central Alps. The first curve is based on the work of Heinimann (1998; in Horton, 2013); and is considered as rare events. The second curve is based on the work of Rickenmann and Zimmermann (1993) on the extraordinary 1987 event in Switzerland. The threshold values for rare and extreme events are given in Eqs. (2) and (3), respectively (Horton et al., 2008, 2013):

$$
\begin{aligned}
& \left\{\begin{array}{lll}
\tan \beta_{\text {thres }}=0.32 S_{\text {uca }}^{-0.2} & \text { if } & S_{\text {uca }}<2.5 \mathrm{~km}^{2} \\
\tan \beta_{\text {thres }}=0.26 & \text { if } & S_{\text {uca }} \geq 2.5 \mathrm{~km}^{2}
\end{array}\right. \\
& \left\{\begin{array}{lll}
\tan \beta_{\text {thres }}=0.31 S_{\text {uca }}^{-0.15} & \text { if } & S_{\text {uca }}<2.5 \mathrm{~km}^{2} \\
\tan \beta_{\text {thres }}=0.26 & \text { if } & S_{\text {uca }} \geq 2.5 \mathrm{~km}^{2}
\end{array},\right.
\end{aligned}
$$

where $\tan \beta_{\text {thres }}$ is the slope threshold, and $S_{\text {uca }}$ is the surface of the upslope contributing area. The main difference between the rare and extreme events occurs for the small catchments with areas between 1 and 10 ha. Thus, using the 

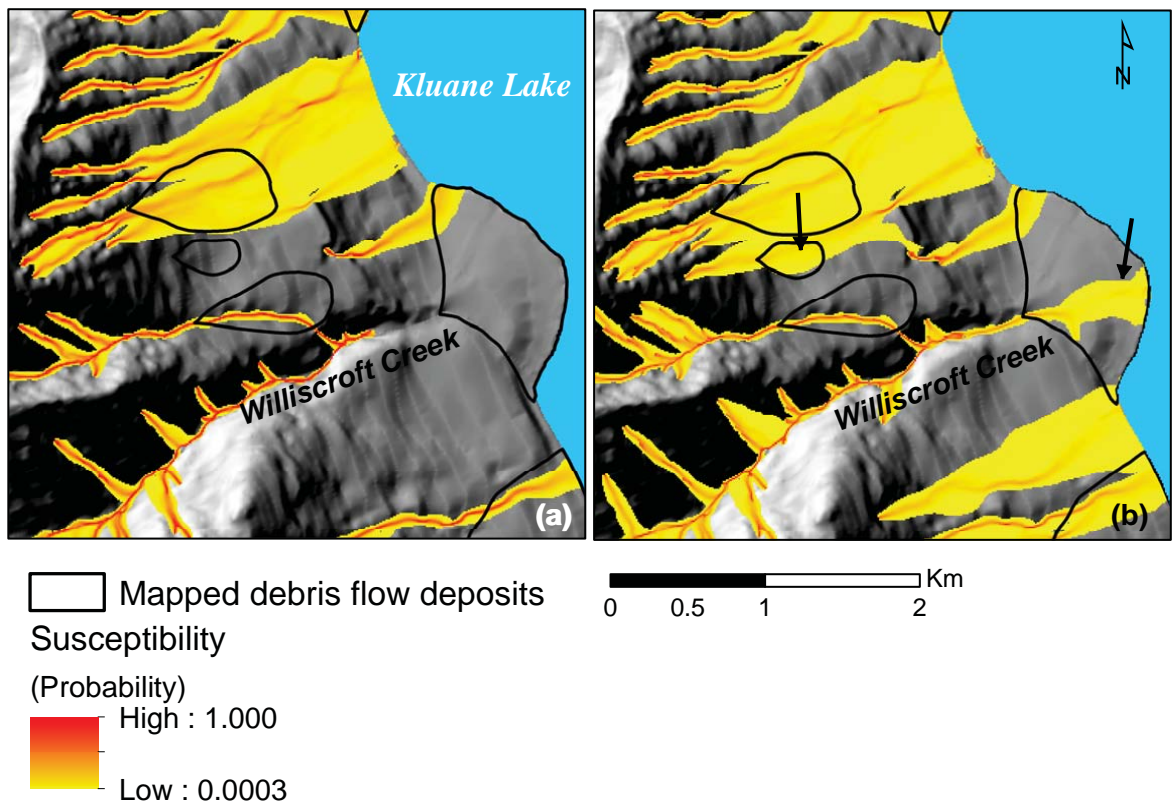

Figure 4. a) The propagation of source areas in and around Williscroft Creek area (box A in Fig. 1): (a) based on the threshold value of $-1.5 / 100 \mathrm{~m}^{-1}$, and (b) based on the threshold value of $-1 / 100 \mathrm{~m}^{-1}$. Note the two debris flow deposits that are captured only in (b) are shown with black arrows.

rare events limit would cause the omission of some potential sources, which are small but still can contribute to a debris flow event (Horton et al., 2008). In order not to miss any potential source area, we decided to use the extreme events limit. Furthermore, comparing the mapped debris flow deposits in the study area with the source areas created using both threshold values (Eqs. 2 and 3) showed that the extreme events limit is more consistent with the past debris flow events along the Yukon Alaska Highway area.

The surficial geology deposits were classified into favourable, excluded, and ignored, based on the type of surficial unit and suitability as being a source for sediments and debris material. The colluvium, till, and the drift units were classified as favourable, the organic material as excluded, and the rest of units as ignored. Once the parameter maps were classified, they were integrated to create the final source areas (Fig. 5). We also compared the estimated catchment source areas for the heuristic method to the calculated source areas from Flow-R. Hence, many of the calculated source areas overlap with the estimated source areas (Fig. 5).

\subsection{Susceptibility assessment}

In order to calculate the potential spread from source areas, we used the Holmgren (1994) method and its modified version as the flow direction algorithms (Horton et al., 2013). Using $\Delta h$ equal to 1 and $2 \mathrm{~m}$ provided somewhat more lateral spreading; except for a few debris flow fans, the effect was not very significant. This was expected for a $10 \mathrm{~m}$ DEM because the change of $\Delta \mathrm{h}$ affects mainly the finer resolu- tion DEMs (Horton et al., 2013). Holmgren (1994) proposed the value of exponent $x$ in the flow direction algorithm in the range of 4 to 6 and Claessens et al. (2005) suggested the value of 4 for debris flows. We applied the value of 4 in most of our simulations and compared the spreading results with the mapped debris flow deposits in the study area. Exponent values equal to 5 and 6 were also tested. These propagation results were not as satisfactory as with $x$ equal to 4 . Therefore, we selected the value of 4 for the rest of the simulations. To set the inertial algorithm which weights the flow proportion based on the persistence function for each direction change $(w)$, we selected the proportional approach which assigns the weights of $1,0.8,0.4,0$, and 0 , for $w_{0}, w_{45}, w_{90}, w_{135}$, and $w_{180}$, respectively.

Perla's (1980) two-parameter friction model was used for the assessment of runout distance. Because there was no information on the mass-to-drag ratio $\omega$ and friction coefficient $\mu$ for the debris flow deposits in the study area, it was decided to calibrate these values by comparing the propagation areas resulting from different sets of $\omega$ and $\mu$ and the mapped debris flow deposits, while keeping the spreading parameters fixed. The tested values range from 10 to 1000 for $\omega$ and 0.01 to 0.3 for $\mu$. The resulting simulations using varying sets of $\omega$ and $\mu$ yield almost similar propagation for most of the debris flow deposits except for the relatively larger ones (Figs. 6 and 7). With $\omega$ equal to 10 and $\mu$ equal to 0.3 , only one very small debris flow deposit was completely reached in runout distance. About $69 \%$ of the mapped debris flow deposits were completely or partly reached when $\omega$ equal to 20 and $\mu$ equal to 0.02 were used. Most of the debris flow 


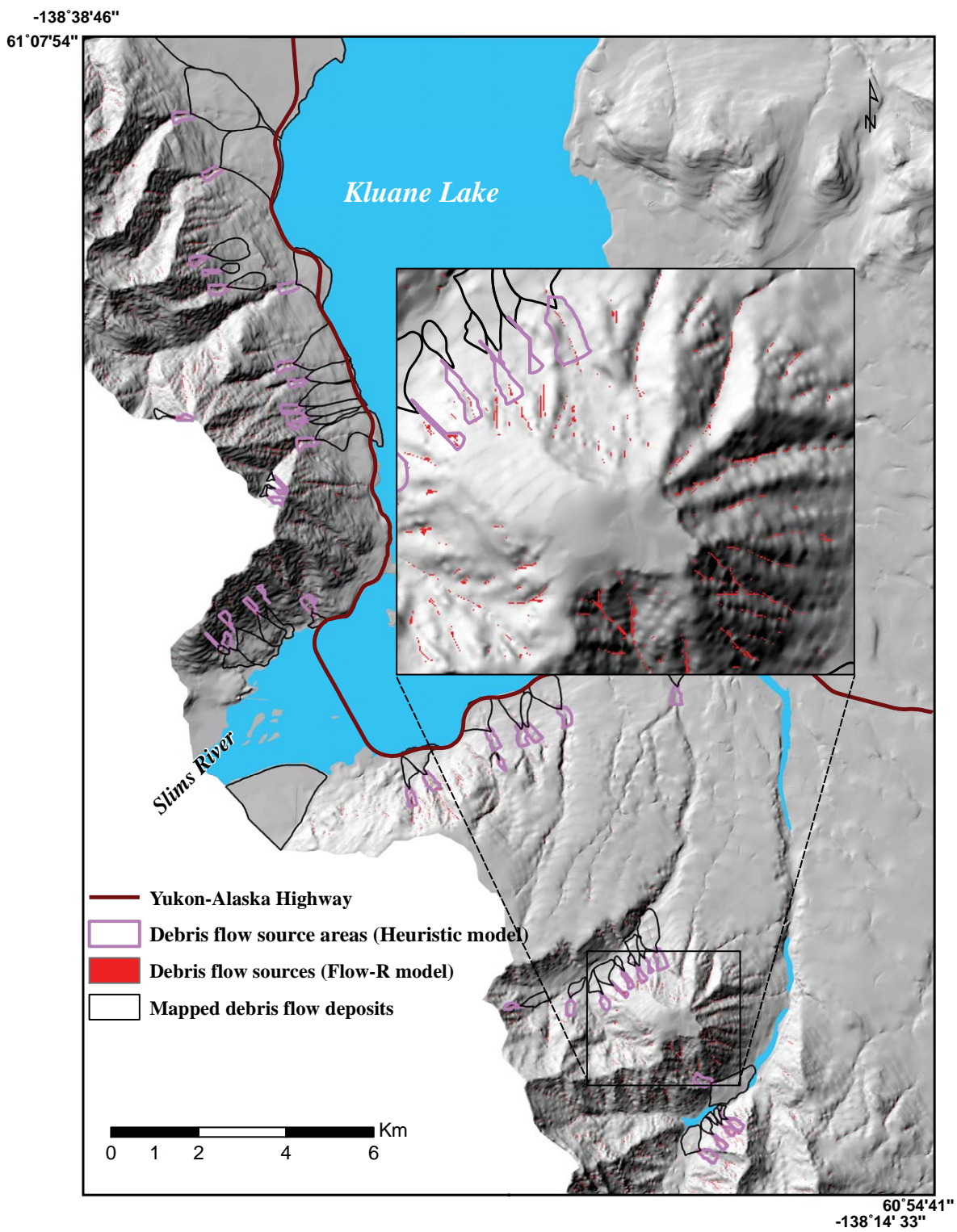

Figure 5. Potential debris flow source areas for the south end of Kluane Lake derived by integrating controlling factors. Inset map displays an enlargement of the calculated source areas (red areas; Flow-R) and the assumed potential source areas (purple lines; Heuristic method). Refer to Fig. 1c for location.

deposits with the exception of two very large and three relatively large fans were reached with $\omega=200$ and $\mu=0.06$. The same result was also achieved with other sets of $\omega$ and $\mu$ (e.g. $\omega=150$ and $\mu=0.05, \omega=100$ and $\mu=0.04$ ). The best fit for the three relatively larger fans (A, B, and C in Fig. 6) were achieved with $\omega=150$ and $\mu=0.02$ because it provided a better fit for these fans, but did not change the propagation pattern for the rest of debris flow deposits (Fig. 6). Of the two very large fans, one is part of a larger fan located in the northwestern edge of the study area (A in Fig. 6) with only a very small portion reached in one area. The source area for this fan is likely located outside of the limit of the study area. The other very large fan, located southeast of Kluane Lake (E in Figs. 6 and 7), is just partly reached when $\omega$ greater than 600 and $\mu$ equal to 0.02 (or $\omega$ greater than 100 at $\mu=0.01$ ) are used (Fig. 7). Further increasing the massto-drag ratio mainly affects the runout distance for fans $\mathrm{C}$, $\mathrm{D}$, and $\mathrm{E}$ and a few channels in the east and northeast of the study area and does not change the propagation pattern for the rest of the area (Figs. 6 and 7). The calculated propagation for fan $\mathrm{E}$ is likely too short in this case because the first source area is located about $6 \mathrm{~km}$ upstream from the apex of this fan. Figure 7 displays correlation with the mapped debris flow deposits (Blais-Stevens, 2010a), but also the ones 


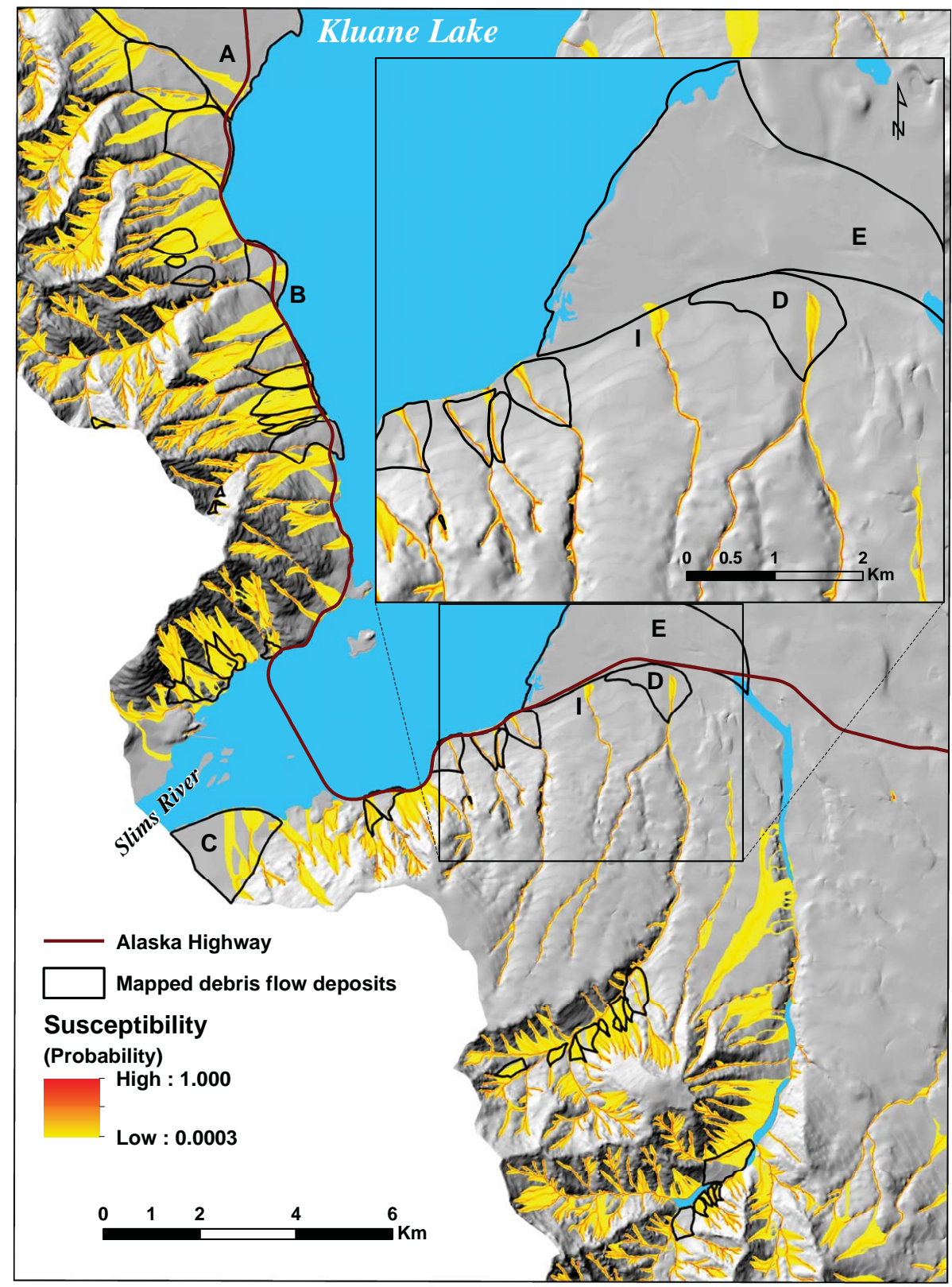

Figure 6. Debris flow susceptibility map derived from propagation of source areas using $\omega=150$ and $\mu=0.02$. Note no propagation reaches debris flow deposit E.

studied in detail by Koch et al. (2014) and those that were documented after the 1988 event (Evans and Clague, 1989; Lipovsky, 2005). Testing various sets of $\omega$ and $\mu$ showed that the runout distance was more sensitive to the friction coefficient rather than mass-to-drag ratio changes, particularly at higher values of $\mu$.

\subsection{Evaluation}

The debris flow susceptibility map created using the propagation of source areas represents the present-day conditions.
The mapped debris flow deposits were used to evaluate the susceptibility map although these deposits likely have been accumulating since deglaciation (Koch et al., 2014) spreading into large fans. Therefore it is expected that the spreading would not cover all of the fan but it should cover at least a part of it in present-day conditions and delineate areas within the fan that are more susceptible to deposition (e.g. red zones). Out of 49 debris flow deposits, most are reached in terms of runout distance, but some of them are not completely covered in terms of lateral spreading. Nevertheless, debris can 


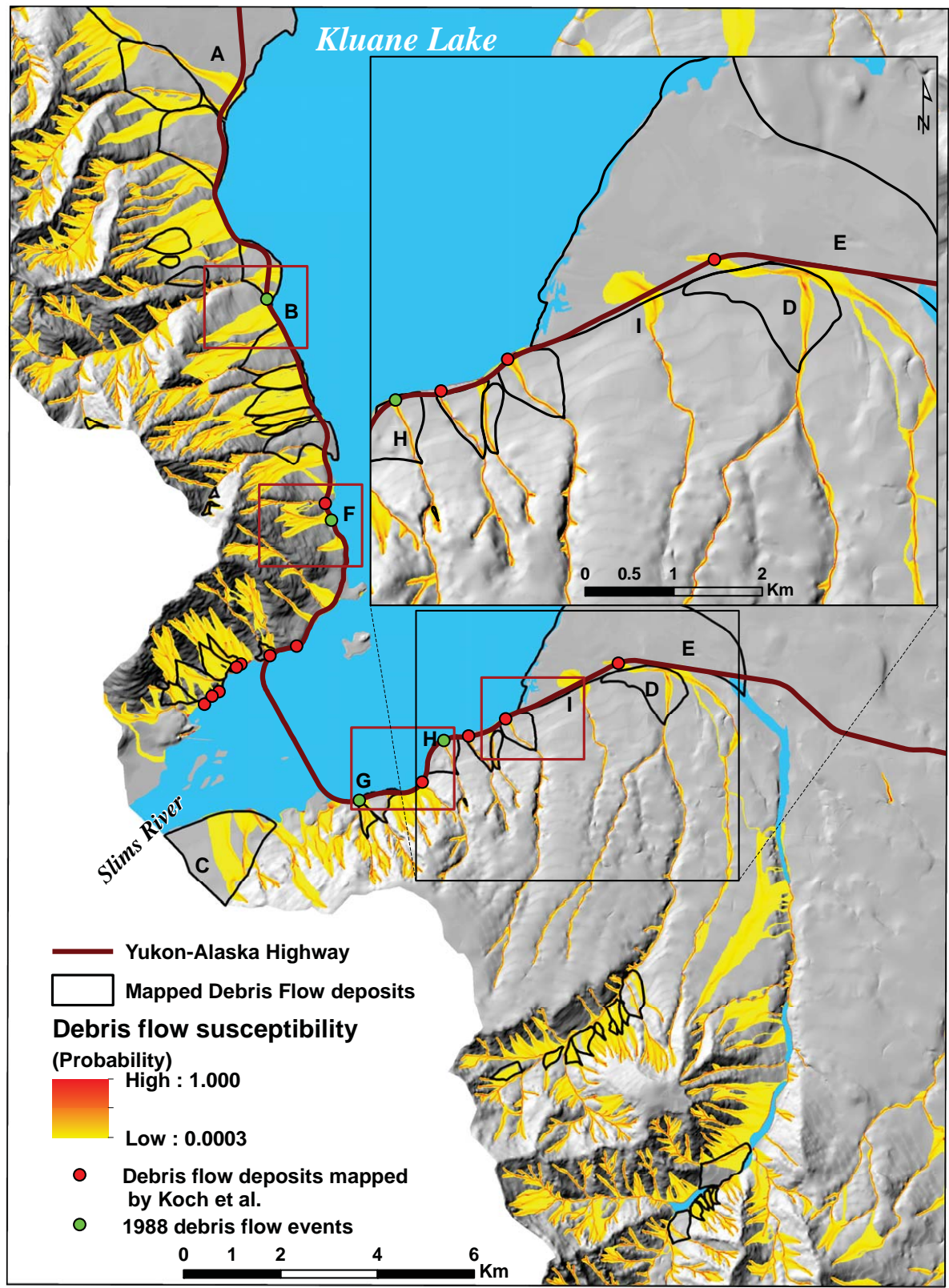

Figure 7. Debris flow susceptibility map derived from propagation of source areas using $\omega=600$ and $\mu=0.02$. Minor propagation is seen reaching the southwest edge of debris flow deposit E. Also note the propagation pattern in C, D, and I. Debris flow susceptibility displays a good correlation with the mapped debris flow deposits (black lines from Blais-Stevens, 2010a), the documented 1988 event from Evans and Clague (1989; green dots), and from the detailed study from Koch et al. (2014; red dots).

still flow, propagate, and block the highway even as relatively small fans (Evans and Clague, 1989).

Debris flows triggered by heavy rains in 1988 and 1967 (locations B, F, G, and H in Figs. 7 and 8) are also used to evaluate the debris flow susceptibility map. Figure 8 displays WorldView-2 images overlaid by the susceptibility map at the location of these events. Williscroft Creek watershed (Figs. 7 and 8a) is a typical active fan along the foot of the Kluane Range (Evans and Clague, 1989) in which the highway was severed at B during heavy rains in July 1988. About $3.5 \mathrm{~km}$ north of Slims River (Fig. 7), two debris flows occurred in Holocene colluvium, one of which blocked the highway at F (Figs. 7, 8b and 9). Another debris flow occurred about $1.5 \mathrm{~km}$ east of Slims River (G in Figs. 7 and 8c) and covered more than $500 \mathrm{~m}$ of the highway (Evans and Clague, 1989). A debris flow triggered by heavy rains during the summer of 1967 (location $\mathrm{H}$ in Figs. 7 and 8c) also blocked the highway. All four locations where the high- 

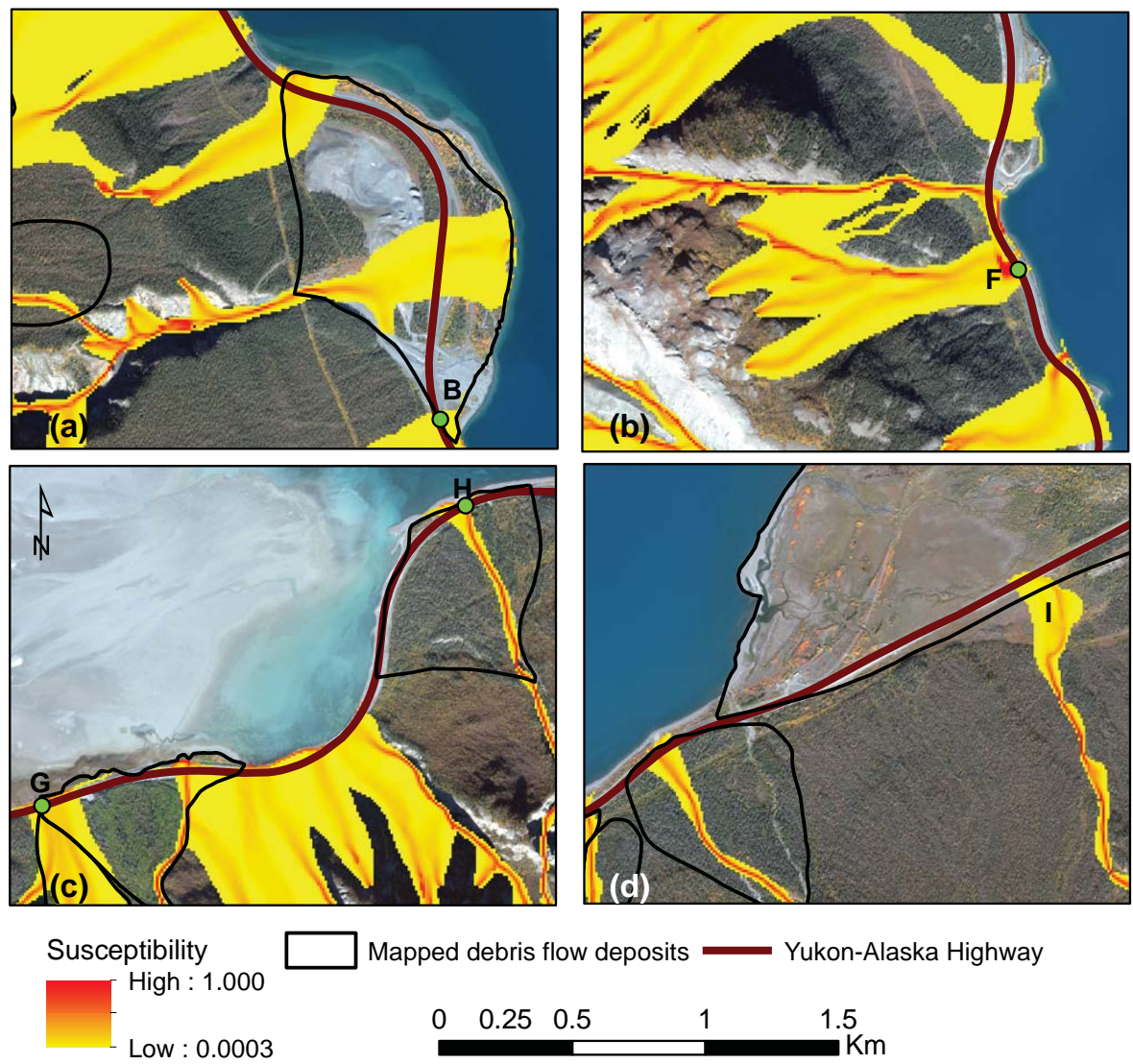

d

Mapped debris flow deposits Yukon-Alaska Highway

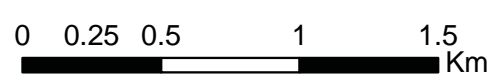

Figure 8. (a), (b), (c). The susceptibility map overlaid on WorldView2 satellite imagery (2010) shows the location of debris flow deposits which blocked the highway in 1988 (B, F, and G) and in 1967 (H). (d) A potential debris flow (I) that could reach the highway.

way was severed are covered by the propagation pattern in the debris flow susceptibility map created using Flow-R. The Williscroft Creek watershed is mainly covered in the middle part, but also is reached at B where the highway was blocked.

Koch et al. (2014) studied 30 large debris flow deposits along the YAHC between Beaver Creek and the south end of Kluane Lake using dendrochronology and tephrochronology to evaluate the potential hazard of debris flows on the highway. A number of 15 debris flow deposits lie in the south end of Kluane Lake (red dots in Fig. 7). Three of them coincide with the 1988 debris flow events documented by Evans and Clague (1989). All except one (Fig. 7) of these fans are captured by the propagation of source areas established using Flow-R.

Nevertheless, the susceptibility map also shows some areas for debris flow deposition that were not outlined as debris lobes in the inventory or other sources. These in some cases extend past the highway (e.g. debris flow I in Figs. 7 and 8d).

\section{Conclusion}

Two separate methods were used to assess the debris flow susceptibility in the YAHC focusing on the northern portion of the corridor for the qualitative heuristic method and the south end of Kluane Lake for the quantitative method using Flow-R.

The qualitative method was based on expert knowledge using geological and geomorphological data layers with assigned weights and class ratings. The resulting susceptibility map displayed the steep channels as high-susceptibility zones for potentially initiating debris flows. For the most part, downstream from the high-susceptibility zones, where the lower-susceptibility zones are identified, is where the mapped debris flow deposits are found. Validation was carried out using 306 debris flow deposits and their source area estimated within $500 \mathrm{~m}$ upstream of the apex of the deposits. A success rate curve demonstrated that about 80 and $90 \%$ of the debris flow sources were predicted within 5.5 and $10.5 \%$ of high-susceptibility areas, respectively. In the southern portion of Kluane Lake, where 1988 debris flow deposits were documented and studied in detail, the susceptibility zones upstream from the location of these deposits are high.

A quantitative approach for debris flow susceptibility focused on a smaller area within the YAHC, at the southern end of Kluane Lake, where historical and pre-historic events had been documented. The Flow-R method allowed us to 


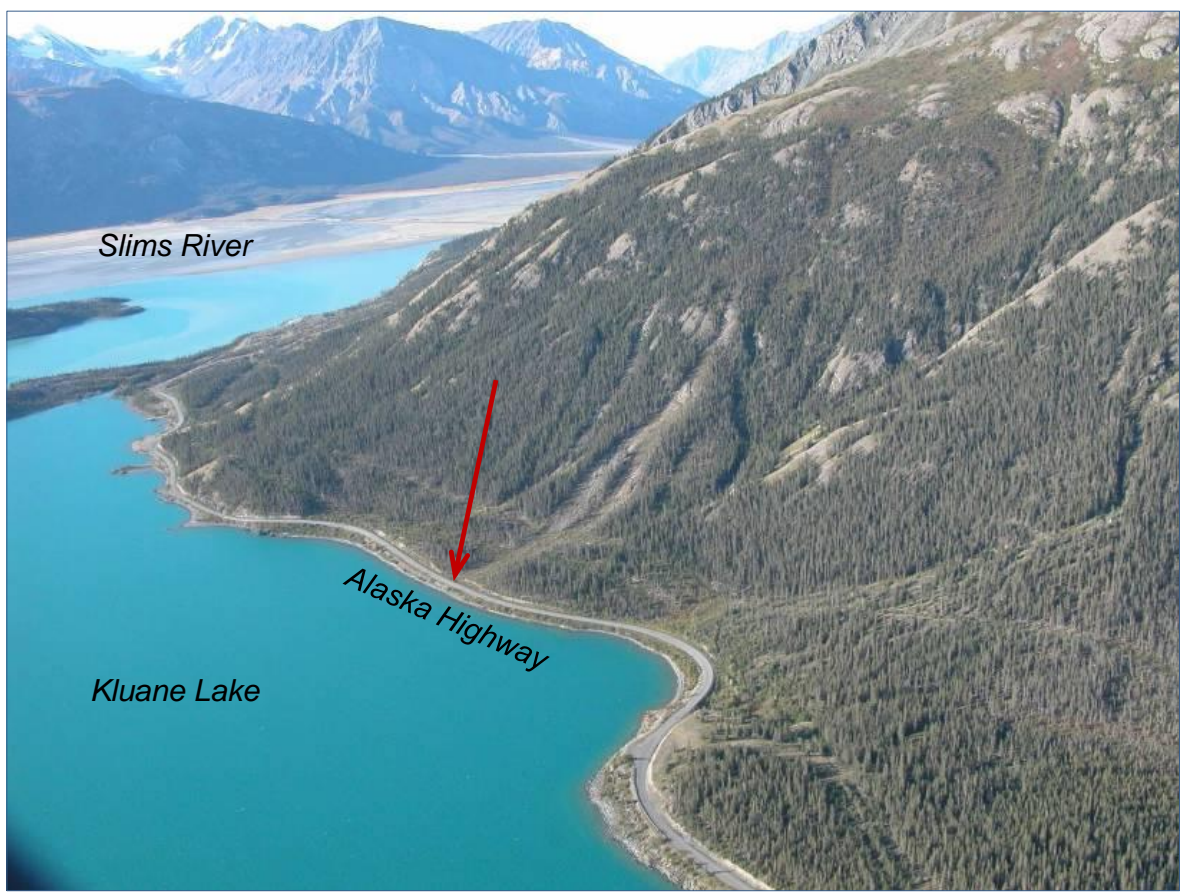

Figure 9. Oblique photo of debris flow channels at Horseshoe Bay, southwestern end of Kluane Lake (photo by C. Huscroft). During the 1988 storm event, debris flow deposits blocked the Alaska Highway (e.g. red arrow) for up to 7 days (Evans and Clague, 1989). (Site F in Figs. 7 and 8b.)

quantitatively determine the potential source areas and also calculate potential spreading and runout. Trial-and-error calculations were needed during the modelling because there was not enough detailed information on the debris flow deposits to calculate threshold values for parameters controlling source area delineation, spreading, and runout distance assessment. Nevertheless, correlation with known documented events helped us define these parameters and produce a map that captures most of the known events and displays debris flow susceptibility in other steep channels. Applying Flow-R method for a large area with varied topography, i.e. using the same threshold values for the whole area, may result in overgeneralization in some areas. However, except the area southeast of Kluane Lake, which is characterized by a flatter topography, the rest of the study area has a similar topography. Besides, using a wide range of values for parameters controlling spreading and runout distance did not change the propagation pattern dramatically, except for a few large and relatively large debris flow deposits.

The debris flow susceptibility map correlates well with known events and has also displayed other potential channels that could be susceptible to debris flows. The correlation with known events may or may not exactly match with the size of the mapped debris flow deposits. This is expected, given that some of these debris flow fans have been building since deglaciation time, while the Flow-R method reflects presentday conditions.
The two debris flow susceptibility regional models were able to delineate areas that have high susceptibility either from the initiation zone (heuristic) or calculated sources and propagation (Flow-R). These are meant to serve a first step in assessing the debris flow hazard. However, for further quantitative hazard assessment, site-specific investigations on magnitude and frequency of events would be needed.

Acknowledgements. This project was funded by Natural Resources Canada's Program of Energy and Research and Development. The authors would like to thank Sharon Smith (Geological Survey of Canada project leader), Panya Lipovsky (Yukon Geological Survey), and John Clague (Simon Fraser University) for their continual input. P. Horton (Terr@num Ltd) is acknowledged for his advice, comments and suggestions. Crystal Huscroft (Thompson River University) is thanked for the photo of Horseshoe Bay. Amaris Page, Marian Kremer, Ariane Castagner, and Joe Koch are acknowledged for their technical assistance. Jeff Harris (Geological Survey of Canada) is also thanked for his comments and suggestions. Pierre Gravel and his colleagues (Canadian Centre for Geospatial Information) are thanked for providing a new high-resolution DEM.

Edited by: O. Katz

Reviewed by: T. Oppikofer and one anonymous referee 


\section{References}

Beguería, S., Van Asch, Th. W. J., Malet, J.-P., and Gröndahl, S.: A GIS-based numerical model for simulating the kinematics of mud and debris flows over complex terrain, Nat. Hazards Earth Syst. Sci., 9, 1897-1909, doi:10.5194/nhess-9-1897-2009, 2009.

Berti, M. and Simoni, A.: Prediction of debris flow inundation areas using empirical mobility relationships, Geomorphology, 90, 144-161, 2007.

Blais-Stevens, A., Couture, R., and Page, A.: Landslide inventory along the Alaska Highway Corridor, Yukon, Geol. Surv. of Can., Ottawa, Ont., Open File 6654, DVD, 2010a.

Blais-Stevens, A., Couture, R., Page, A., Koch, J., Clague, J. J., and Lipovsky, P.: Landslide susceptibility, hazard and risk assessments along pipeline corridors in Canada, in: Proceedings of the 63rd Canadian geotechnical conference and 6th Canadian permafrost conference, Calgary (AB), 878-885, 2010b.

Blais-Stevens, A. Lipovsky, P., Kremer, M., Couture, R., and Page, A.: Landslide inventory and susceptibility mapping for a proposed pipeline route, Yukon Alaska Highway Corridor, in: Proceedings of the Second World Landslide Forum, Rome, Italy, 362, (ESS Cont. \# 20110101), 2011.

Blais-Stevens, A. Lipovsky, P., Kremer, M., Couture, R., and Smith, S.: Landslide inventory and susceptibility mapping for the Yukon Alaska Highway Corridor, in: Proceedings of the 11th International and 2nd North American Symposium on landslides and engineered slopes, Banff, Alberta, 1, 777-782, 2012.

Blais-Stevens, A., Kremer, M., Bonnaventure, P. P., Smith, S. L., Lipovsky, P. and Lewkowicz, A. G.: Active layer detachment slides and retrogressive thaw slumps susceptibility mapping for present-day and projected climate conditions along the Yukon Alaska Highway Corridor - A qualitative heuristic approach, in: Proceedings of the Engineering Geology for Society and territory, IAEG conference, Torino, Springer, 1, 449-453, (GSC Contribution: 20130369), 2014.

Chung, C.-J. F. and Fabbri, A. E.: Validation of spatial prediction models for landslide hazard mapping, Nat. Hazards, 30, 451472, doi:10.1023/B:NHAZ.0000007172.62651.2b, 2003

Claessens, L., Heuvelink, G. B. M., Schoorl, J. M., and Veldkamp, A.: DEM resolution effects on shallow landslide hazard and soil redistribution modelling, Earth Surf. Proc. Land., 30, 461-477, doi:10.1002/esp.1155, 2005.

Costa, J. E.: Physical geomorphology of debris flows, in: Developments and Applications of Geomorphology, edited by:Costa, J. E. and Fleisher, P. J., Berlin, Springer-Verlag, 268-317, 1984.

Couture, R., Blais-Stevens, A., Page, A., Koch, J., Clague, J. J., and Lipovsky, P. S.: Landslide susceptibility, hazard and risk assessment along pipelines in Canada, in: Proceedings of the 11th International Association for Engineering Geology and the Environment Congress, edited by: Williams, A. L., Pinches, G. M., Chin, C. Y., McMorran, T. J., and Massey, C. I., Auckland, New Zealand, 5-10 September, 1023-1031, 2010.

Dai, F. C. and Lee, C. F.: Terrain-based mapping of landslide susceptibility using a geographical information system: a case study, Can. Geotech. J., 38, 911-923, doi:10.1139/cgi-38-5-911, 2001.

Evans, S. G. and Clague, J. J.: Rain-induced landslides in the Canadian Cordillera, July 1988, Geos. Canada, 16, 193-200, 1989.
Fischer, L., Rubensdotter, L., Sletten, K., Stalsberg, K., Melchiorre, C., Horton, P., and Jaboyedoff, M.: Debris flow modeling for susceptibility mapping at regional to national scale in Norway, in: Proceedings of the 11th International and 2nd North American Symposium on Landslides, Banff, Alberta, Canada, 3-8 June 2012, 723-729, 2012.

Gamma, P.: dfwalk - Ein Murgang-Simulationsprogramm zur Gefahrenzonierung, Geographisches Institut der Universität Bern, 2000.

Gordey S. P. and Makepeace, A. J.: Yukon digital geology, version 2.0 Geol. Surv. of Can., Ottawa, Ont., Open File 1749 and Yukon Geol. Surv., Whitehorse, Yukon, Open File 2003-9(D), 2 CD-ROMS, 2003.

Heinimann, H. R.: Methoden zur Analyse und Bewertung von Naturgefahren, Bundesamt für Umwelt, Wald und Landschaft, (BUWAL), 85, 247 pp., 1998.

Holmgren, P.: Multiple flow direction algorithms for runoff modelling in grid based elevation models: An empirical evaluation, Hydrol. Process., 8, 327-334, doi:10.1002/hyp.3360080405, 1994.

Horton, P., Jaboyedoff, M., and Bardou, E.: Debris flow susceptibility mapping at a regional scale, in: Proceedings of the 4th Canadian Conference on Geohazards, Québec, Canada, 2008, 399406, 2008.

Horton, P., Jaboyedoff, M., Rudaz, B., and Zimmermann, M.: Flow$\mathrm{R}$, a model for susceptibility mapping of debris flows and other gravitational hazards at a regional scale, Nat. Hazards Earth Syst. Sci., 13, 869-885, doi:10.5194/nhess-13-869-2013, 2013.

Hungr, O., Morgan, G. C., and Kellerhals, R.: Quantitative analysis of debris torrent hazards for design of remedial measures, Can. Geotech. J., 21, 663-677, 1984.

Huscroft, C. A., Lipovsky, P. S., and Bond, J. D.: A regional characterization of landslides in the Alaska Highway corridor, Yukon, Yukon Geol. Surv., Whitehorse, Yukon, Open File Rep. 2004-18, 65 pp., 2004.

Hussin, H. Y., Quan Luna, B., van Westen, C. J., Christen, M., Malet, J. P., and van Asch, Th. W. J.: Parameterization of a numerical 2-D debris flow model with entrainment: a case study of the Faucon catchment, Southern French Alps, Nat. Hazards Earth Syst. Sci., 12, 3075-3090, 2012.

Koch, J., Clague, J. J., and Blais-Stevens, A.: Debris flow chronology and potential hazard along the Alaska Highway in southwest Yukon Territory, Environ. Eng. Geosci., 25-43, 2014.

Lipovsky, P. S.: Rapid landscape change and human response in the Arctic and sub-Arctic, an interdisciplinary conference, Field guide, Yukon College, Whitehorse, Yukon, 43-101, 2005.

Mathews, W. H.: Physiographic map of the Canadian Cordillera, Geol. Surv. Can., Ottawa, Ont., 1 : 5000000 scale, 1986.

Ortigao, J. A. R. and Kanji, M. A.: Landslide classification and risk management, in: Handbook of Slope Stabilization, edited by: Oritgao, J. A. R. and Sayao, A. S. F. J., Springer Verlag, Heidelberg, 27-66, 2004.

Park, D., Lee, S., Nikhil, N. V., Kang, S., and Park, J.: Debris flow hazard zonation by probabilistic analysis (MT. Woomyeon, Seoul, Korea), IJIRSET, 2, 2381-2390, 2013.

Perla, R., Cheng, T. T., and McClung, D. M.: A two-parameter model of snow-avalanche motion, J. Glaciol., 26, 197-207, 1980. 
Rickenmann, D. and Zimmermann, M.: The 1987 debris flows in Switzerland: documentation and analysis, Geomorphology, 8, 175-189, 1993.

Riopel, S., Couture, R., and Tewari, K.: Mapping susceptibility to landslides in a permafrost environment: case study in the Mackenzie Valley, Northwest Territories, GeoTech Event, Ottawa, Canada, 18-21 June, 13 pp., 2006.

Savage, W. and Baun, R.: Instability of steep slopes, in: Debrisflow hazards and related phenomena, edited by: Matthias, J. and Oldrich, H., Springer, Berlin, Heidelberg, 53-70, 2005.

Soeters, R. and van Westen, C. J.: Slope instability recognition, analysis, and zonation, in: Landslides, investigation and mitigation, edited by: Turner, A. K. and Schuster, R. L., Transportation Research Board, National Research Council, Special Report 247, National Academy Press, Washington, DC, 129-177, 1996.
Takahashi, T.: Estimation of potential debris flows and their hazardous zones: Soft countermeasures for a disaster, Nat. Disaster Sci., 3, 57-89, 1981.

van Westen, C. J., Castellanos, E., and Kuriakose, S. L.: Spatial data for landslide susceptibility, hazard, and vulnerability assessment: An overview, Eng. Geol., 102, 112-131, 2008.

Yukon Geological Survey, http://www.geology.gov.yk.ca/digital_ surficial_data.html, last access: 21 April 2015. 